PESHAWAR JOURNAL OF PSYCHOLOGY AND BEHAVIORAL SCIENCES, 2017, VOL. 3, NO.1, 105-121

\title{
Workaholism an Outcome of Childhood Experiences and its Effect on Health and Sleep
}

\section{Madiha Asghar ${ }^{1}$, Sareer Badshah ${ }^{2}$}

Islamia College Peshawar

\author{
and \\ Maher Bano ${ }^{3}$ \\ Preston University, Peshawar
}

This study aims at exploring the factors associated with workaholism. A total of three hundred and sixty one $(\mathrm{N}=361)$ (Workaholics=175, Non-workaholics=186) working adults, ranging from 25 to 59 years of age with educational background of at least bachelor's degree from different departments in Peshawar, Khyber Pakhtunkhwa, Pakistan were recruited. In this report workaholics were compared to non-workaholics on measures of test for workaholism and self-designed questionnaire. It was found that educational level, age, economic crisis during childhood, and health-related problems such sleep disorders and hypertension were independently associated with workaholics as compared to non-workaholics. Childhood family experiences were also investigated and it was found that workaholism was an outcome of disturbed family experiences in early years of life. It was concluded that workaholism plays an important role in improving the standard of workaholics' personal, family and professional life materially but at the cost of their own health. This study recognizes workaholism in Peshawar and would help recommend policies and health awareness in this region.

Keywords: workaholism, dysfunctional family, economic crisis, age, sleep problems and hypertension.

Work may be a duty, a purposeful effort, time spent at the place of employment. It is not only a source of earning livelihood but also plays an important role in winning self-recognition, prestige, status, satisfaction and self-worth (Golińska, 2008). People spend a good part of the day to

1 Assistant Professor, Department of Psychology, Islamia College Peshawar

2 Professor and Chairman, Department of Statistics, Islamia College Peshawar

3 Professor, Department of Psychology, Preston University, Peshawar 
meet their needs and demands, which is why the work can be regarded as a reflection of the needs and demands of the individual who performs it (Smith \& Cronje, 2001). The term workaholism was first introduced by Oates (1968), workaholism term was derived from the term alcoholism. He said that there were similarities between workaholics and alcoholics. Machlowitz (1980) further described the term workaholism in terms of long working hours. Several researchers proposed different kinds of workaholics (Burke, 2000; Fassel, 1990; Naughton, 1987; Oates, 1971; Robinson; 1998; Scot et al, 1997; and Spence and Robbins, 1992).

When work becomes an excess and compulsion, the worker feels unable to control work habits, exhibits impaired communication, difficulty delegating responsibilities and impaired self-worth. It means the person has become a work addict or workaholics (Flowers and Robinson, 2001).

Workaholism can be regarded as an attempt to escape the difficulties of life through too much work. Similarly, Klaft and Kleiner (1988) believe that workaholics' intent towards work is the escape from or avoidance of problems in their lives. Family environmental variables have always been considered important in studying human behavior. Dysfunctional family refers to any circumstance that interferes with healthy family functioning. As Thorne (1987) investigated the causes of addiction to work and also the extent that work addicts lose control over their lives so that work becomes a drug. The reasons may include mishaps in the early development of self-image. Work becomes a drug in order to feel more important and less inadequate. The desire to escape fear has also been cited as a cause of workaholism. Bartolome (1983) distinguished between the workaholic and the non-workaholic "prisoner of success" by stating that workaholics make efforts to escape their private lives through over-commitment to work, whereas non-workaholics who may work too much simply neglect their private lives as they attempt to succeed. The difference is in the intent of the worker. Minirth et al. (1991) supports this idea: A workaholic is anyone who keeps himself/herself busy to avoid getting in touch with personal feelings, to stay away of intimacy. Earlier, Oates (1971) postulated that children who have been deprived economically, culturally and emotionally may develop workaholism in adulthood.

Work for more than 60 (sixty) hours per week is defined by Otake and Okudaira (2008) as workaholism. The notion of workaholism is mostly associated with long working hours and may lead to health-related 
problems (Burke, Mattheisen \& Pallesen, 2006; Robinson and Post, 1995, 1997). Studies of different researchers (Fujimoto 2014 and Shimazu et al. 2012) revealed an association between workaholism with psychological distress and physical health problems.

Work and health are two important factors of human life and both are necessary for a satisfied and prosperous living. For thousands of years work has been the major activity of life. As work time increases, people adjust their work demand at the cost of decreased sleeping hours (Overman, 1999; Shellenbarger, 1999). Extended working hours brings better changes in the personal and societal level, but may have negative impacts on the wellbeing of the workers themselves (Surgeon, Harrington and Cooper, 1997). Further, the term workaholism was described by Oates (1968) as an uncontrollable excessive need to work at the cost of the individual's health and happiness. Similarly according to Burke, et al., (2006), workaholism leads to health-related problems.

According to the results of the Kubota et al. (2011) there was a positive association between insomnia and workaholism, however other sleep related problems such as drowsiness, feeling tired upon rising up, and difficulty in waking up. Similar finds were revealed by Fujimoto (2014) focusing on the significance of relationship between workaholism and sleep problems. Many researchers supported the idea that workaholism leads to physical health problems that is inability to sleep, headache, hypertension, heart diseases, etc due to obsessive work habits (Spence and Robinson, 1992). The strong association between work and health status is viewed as two important interrelated factors of the human resource. Health is the physical, mental and social wellbeing of an individual and not merely the absence of the disease (World Health Organization, 1946). This definition leads to the conclusion that the human resource's priority is to maintain the complete health status so that people are able to learn and perform properly any task assigned to them. As a matter of fact the prosperity of the individuals, their families and the society at large depends on the health of the human resource.

\section{Objectives}

- To ascertain the differences in childhood experiences of workaholics and non-workaholics

- To investigate the difference between the health status and sleep of workaholics and non-workaholics 


\section{Hypotheses}

- Workaholics will report more negative childhood experiences as compared to non-workaholics

- Workaholics will reveal more health related problems as compared to non-workaholics

- Workaholics will report more sleep related problems as compared to non-workaholics

\section{Method}

\section{Participants}

The sample of 361 adult volunteers (male $=178$ and female $=183$ ) workaholics $(n=175)$ and non-workaholics $(n=186)$, drawn from different professions that included teachers, doctors, lawyers, policemen and administrators in different organizations of Peshawar (Khyber Pakhtunkhwa, Pakistan) through convenient sampling; who work greater than the required time in their respective professions were recruited for this study. Fulltime working employees were selected who reported 50 hours per week time spent in work (mean time 61.29, $\mathrm{SD}=5.16$ ) against non-workaholics with the average working hours of 39.75 per week $(\mathrm{SD}=$ $5.53)$.

\section{Measures}

\section{Workaholism Test}

Workaholism test developed by Neil Fiore (1998)T.he scale contained 24 items on 5-Point Likert Scale ranging from 1 (Not at all true) to 5 (Mostly true) were used. The reliability coefficient for this scale was 0.95. The scores on the scale ranged between a minimum of 24 and maximum of 120 and the cut-off point was 48. Scores for nonworkaholics was decided to be 25 to 48 , low from 49 to 72 , and 73 to 96 for moderate whereas 97 to 120 scores was used for high workaholics. Highest score (97 to 120) on the scale was used for workaholism.

\section{Personal Information Schedule}

Personal informational schedule is aimed at collection of demographic information and details of early life history of the subjects. It consists of five main parts; Part 1 includes basic demographic information (i.e. age, gender, marital status, education, occupation, 
monthly income and parental death during early age of life, parental separation, polygamy by father, severe illness of parent(s), and father working away from home. The Part 2 probes into the impact of marital relationships of parents of workaholics and non-workaholics. The Part 3 tries to trace the nature of control and support as modes of discipline received by subjects in his/her early years of life. The Part 4 attempts to trace the previous socioeconomic status, economic crisis of the subject during his or her early years of life and the desire for becoming rich. The Part 5 includes the present health status of the subjects.

\section{Procedure}

The researcher visited each institution and contacted the subjects individually. The aims and objectives of the research were briefly explained to each subject. A proper schedule was prepared for testing after obtaining approval from each participant. Each participant was contacted according to the time and venue as per schedule. Before administering the test, an effort was made to develop a rapport with subjects. After a brief description about the nature of research work, they were assured that the results would be kept confidential. They were assured that the information thus elicited would be used only for research purpose.

In the present study, it was not possible to have groups of workaholics available for test administration, therefore the researcher decided to administer the test individually for sake of uniformity of procedure. Before administering each test, instructions were read out to the subjects, and if needed, further explanation was also offered to ascertain the understanding of the test by the subjects. Following the introductory step, subjects, who volunteered for this study, were given consent form, workaholism test and self-constructed information sheet seeking family history with the instructions to fill out the sheet and return it to the researcher.

\section{Results}

The sample of the present study consisted of 361 fulltime employees workaholics $(n=175$, mean age 32.74, SD 7.148) and nonworkaholics $(n=186$, mean age 32.18 , SD 7.983) whose educational level was at least graduate. Univariate Analysis (Odd Ratio) was used to investigate the important factors. Multivariate analysis (Logistic 
regression) method was used to identify the independent influential factors associated with workaholics compared to non-workaholics.

Table 1

Univariate and Multivariate Analysis of Psychosocial and Familial Determinants of Workaholism against Non-workaholism.

\begin{tabular}{|c|c|c|c|c|c|c|}
\hline Variables & $\begin{array}{l}\text { Workaholics } \\
\mathrm{n}=175(48.5)\end{array}$ & $\begin{array}{c}\text { Non- } \\
\text { workaholics } \\
\mathrm{n}=186(51.5)\end{array}$ & $\begin{array}{l}\text { Odd } \\
\text { Ratio }\end{array}$ & $p$ & $\begin{array}{l}\text { Adjusted } \\
\text { Odd } \\
\text { Ratio }\end{array}$ & $p$ \\
\hline \multicolumn{7}{|c|}{ Demographic factors } \\
\hline \multicolumn{7}{|c|}{ Gender } \\
\hline Female & $98(53.6)$ & $85(46.4)$ & 1.51 & .051 & - & - \\
\hline Male & $77(43.3)$ & $101(56.71)$ & - & - & - & - \\
\hline \multicolumn{7}{|l|}{ Education } \\
\hline M.Phil/PhD & $37(60.7)$ & $24(39.3)$ & 6.25 & 0.001 & 19.57 & 0.001 \\
\hline M.A & $121(56.8)$ & $92(43.2)$ & 5.41 & 0.001 & 14.97 & 0.001 \\
\hline BA & $17(19.5)$ & $70(80.5)$ & - & - & - & - \\
\hline \multicolumn{7}{|l|}{ Marital } \\
\hline \multicolumn{7}{|l|}{ Status } \\
\hline Married & $81(55.1)$ & $66(44.9)$ & 1.56 & .037 & - & - \\
\hline $\begin{array}{l}\text { Unmarried } \\
\text { Age in years }\end{array}$ & $94(43.9)$ & $120(56.1)$ & - & - & - & - \\
\hline$\geq 36$ & $40(41.2)$ & $57(58.8)$ & 1.59 & 0.10 & 1.20 & .67 \\
\hline $28-35$ & $97(69.3)$ & $43(30.7)$ & 5.11 & 0.001 & 9.10 & .001 \\
\hline$\leq 27$ & $38(30.6)$ & $86(69.4)$ & - & - & - & - \\
\hline \multicolumn{7}{|c|}{ Socioeconomic status } \\
\hline \multicolumn{7}{|c|}{ Socioeconomic Status } \\
\hline Lower Class & $34(61.8)$ & $21(38.2)$ & 1.89 & .03 & - & - \\
\hline Middle Class & $141(46.1)$ & $165(53.9)$ & - & - & - & - \\
\hline \multicolumn{7}{|c|}{ Economic Crisis Faced } \\
\hline Yes & $69(71.1)$ & $28(28.9)$ & 3.67 & .001 & 3.63 & 0.001 \\
\hline No & $106(40.2)$ & $158(59.8)$ & - & - & & \\
\hline \multicolumn{7}{|l|}{$\begin{array}{l}\text { Desire to be } \\
\text { rich }\end{array}$} \\
\hline Yes & $114(59.1)$ & $79(40.9)$ & 2.53 & .001 & - & - \\
\hline No & $61(36.3)$ & $107(63.7)$ & - & - & - & - \\
\hline \multicolumn{7}{|l|}{ Monthly } \\
\hline \multicolumn{7}{|l|}{ Income } \\
\hline$\geq 15001$ & $72(66.1)$ & 37 (33.9) & 2.62 & 0.001 & - & - \\
\hline $10001-15000$ & $41(38.3)$ & $66(61.7)$ & 0.83 & 0.48 & - & - \\
\hline$\leq 10000$ & $62(42.8)$ & $83(57.2)$ & - & - & - & - \\
\hline \multicolumn{7}{|c|}{ Parental status } \\
\hline \multicolumn{7}{|c|}{ Father Alive } \\
\hline No & $52(48.6)$ & $55(51.4)$ & 1.01 & .97 & & \\
\hline Yes & $123(48.4)$ & $131(51.6)$ & & & - & - \\
\hline Mother Alive & & & & & & \\
\hline
\end{tabular}

PESHAWAR JOURNAL OF PSYCHOLOGY AND BEHAVIORAL SCIENCES, 2017, VOL. 3, NO. 1, 105-121 


\begin{tabular}{|c|c|c|c|c|c|c|}
\hline WORKAHOLIS & N OUTCOME & HILDHOOD EX & IENCES & & & 111 \\
\hline No & 30 (78.9) & $8(21.1)$ & 4.60 & .001 & & \\
\hline Yes & $145(44.9)$ & $178(55.1)$ & & & - & - \\
\hline Parental & & & & & & \\
\hline Death & & & & & & \\
\hline Both Dead & $20(95.2)$ & $1(4.8)$ & 1.77 & 0.003 & - & - \\
\hline $\begin{array}{l}\text { Death of } \\
\text { single }\end{array}$ & $42(40.4)$ & $62(59.6)$ & 0.75 & 0.20 & - & - \\
\hline Both Alive & $113(47.9)$ & $123(52.1)$ & - & - & - & - \\
\hline Parent Sepa & & & & & & \\
\hline No & $10(90.9)$ & $1(9.1)$ & 11.21 & .02 & & \\
\hline Yes & $165(47.1)$ & $185(52.9)$ & & & - & - \\
\hline Polygamy & & & & & & \\
\hline No & $20(66.7)$ & $10(33.3)$ & 2.27 & .04 & - & - \\
\hline Yes & $155(46.8)$ & $176(53.2)$ & - & - & - & - \\
\hline Parental Mc & al disharmon & & & & & \\
\hline High & 32 (69.6) & $14(30.4)$ & 7.35 & 0.001 & 12.39 & .001 \\
\hline Moderate & $106(66.7)$ & 53 (33.3) & 6.43 & 0.001 & 9.11 & .001 \\
\hline Mild & $37(23.7)$ & $119(76.3)$ & - & - & - & - \\
\hline Parental Be & dden illness & & & & & \\
\hline No & $49(60.5)$ & $32(39.5)$ & 1.87 & .015 & - & - \\
\hline Yes & $126(45.0)$ & $154(55.0)$ & - & - & - & - \\
\hline Child reari & practices & & & & & \\
\hline $\begin{array}{l}\text { Father work } \\
\text { home }\end{array}$ & away from & & & & & \\
\hline No & 36 (67.9) & $17(32.1)$ & 2.57 & .003 & - & - \\
\hline Yes & $139(45.1)$ & $169(54.9)$ & - & - & - & - \\
\hline Dominant $P$ & & & & & & \\
\hline Mother & $55(64.7)$ & $30(35.3)$ & 2.38 & .001 & - & - \\
\hline Father & $120(43.5)$ & $156(56.5)$ & - & - & - & - \\
\hline Parental dis & line & & & & & \\
\hline High & $28(68.3)$ & $13(31.7)$ & 2.97 & 0.003 & - & - \\
\hline Moderate & $68(51.1)$ & $64(48.5)$ & 1.45 & 0.09 & - & - \\
\hline Mild & $79(42.0)$ & $109(58.0)$ & - & - & - & - \\
\hline Health stat & & & & & & \\
\hline Problem & & & & & & \\
\hline Sleeping & & & & & & \\
\hline Always & $65(65.7)$ & $34(34.3)$ & 4.74 & 0.001 & 11.93 & .001 \\
\hline Sometimes & $66(60.6)$ & $43(39.4)$ & 3.80 & 0.001 & 2.46 & .01 \\
\hline Rarely & $44(28.8)$ & $109(71.2)$ & - & - & - & - \\
\hline Headache o & omachache & & & & & \\
\hline Sometimes & $56(60.2)$ & $37(39.8)$ & 2.73 & 0.001 & - & - \\
\hline Always & $48(69.6)$ & $21(30.4)$ & 2.50 & 0.001 & - & - \\
\hline Rarely & $71(35.7)$ & $128(64.3)$ & - & - & - & - \\
\hline Hypertensio & & & & & & \\
\hline Always & $24(96.0)$ & $1(4.0)$ & 33.32 & 0.001 & 171.38 & .001 \\
\hline Sometimes & $30(63.8)$ & $17(36.2)$ & 2.50 & 0.006 & 3.92 & .01 \\
\hline Rarely & $121(41.9)$ & $168(58.1)$ & - & - & - & - \\
\hline
\end{tabular}

PESHAWAR JOURNAL OF PSYCHOLOGY AND BEHAVIORAL SCIENCES, 2017, VOL. 3, NO. 1, 105-121 
Table 1 shows that the factors important at Univariate level are educational level, age, social class, economic crisis faced, desire to get rich, monthly income, parental death, parental separation, polygamy, parental marital disharmony, parental bedridden illness, father working away from home, dominant parents and parental discipline. The effect of workaholism was also noted and it was found that workaholics were at a higher risk of sleeping problems (such as difficulty in sleeping), headache and hypertension compared to non-workaholics.

Logistic regression showed that four factors (i.e. educational level, age, economic crisis faced and parental marital disharmony) were independently associated with workaholics, whilst workaholics were at a higher risk of sleeping problems and hypertension compared to nonworkaholics (Table 1).

\section{Discussion}

The research examined the factors affecting workaholism and consequences of workaholism comparing workaholics and nonworkaholics. The investigation replicated several previous studies and extended this work by incorporating new factors and conclusions as well as collecting data in another country (Pakistan).

Of the demographic variables related to workaholism, age, education and high monthly income were found to be independently associated with workaholism(Burke, 2001). Univariate and multivariate (logistic regression) analysis of the data showed significant relation between workaholism and age. It was further found that age between 2835 years is independently associated with workaholism compared to the age $<27$ years, and $>36$ years, respectively of workaholics comparing with nonworkaholics. Education was also found to be independently associated with workaholism. It can thus be concluded that workaholics succeed in gaining high status in life materially.

Work is an important source of earning livelihood and meeting the needs of individual and their dependents. Every individual strives for satisfaction in life and if the economic conditionsare favorable, the individuals will enjoy all the facilities of life from basic to the luxuries of life. The findings of the this study suggest that greater number of workaholics reported economic crisis faced during their childhood and in order to avoid those calamities of economic crisis, the desire to become rich may develop. Children raised in poverty with economic crises usually have less enjoyable childhood. Therefore they see their adulthood with 
reduced opportunities and happiness (Brooks-Gunn and Duncan, 1997 \& Mayer, 1997). Extrinsic job rewards such as money (Brett \& Stroh, 2003) and escape from the unpleasant events of life in the form of economic crises faced during childhood and fear of being confronted with those situations again in life may take an individual towards overwork which might further turn him/her towards workaholism.

Most of the literature on the psychological and familial correlates of workaholism indicated that workaholism is a consequence of family dysfunction in childhood (Fassel, 1990; Robinson, 1989, 1990, 1992; Woititz, 1987). Childhood is a base forming preparatory period of life towards adulthood. Parents serve two important roles -- the first is provision of basic need by providing their children with basic necessities and materialistic items; the second is taking care of the children and providing them social and emotional support. According to the theory of McMillan and O'Dristoll (2008), workaholics are raised in dysfunctional families, that includes unclear parent-child boundaries, over responsibility and children playing the role of a parent may lead to workaholism. Children who experience lack of parent-child bonding, low emotional attachment, and other negative experiences in childhood may lead to behavioral problems related to work (Golińska, 2006 and Wojdylo, 2010). Workaholism is most likely developed through reinforcement and socialization experiences. Many aspects of family and parenting play roles in socialization. An abundance of research evidence suggested that access to social support is critical to maintenance of health and wellbeing (Berkman, Vaccarino, \& Seeman, 1993). For instance Robinson (1996) contends that workaholism is primarily a consequence of dysfunctional family system. Early parental support and parental presence of at least one or both may influence the evolving structure and quality of social relations and support over the life course (Antonucci \& Akiyama, 1987). This description fits well into the workaholics of the present research who reported death of both parents during childhood compared with nonworkaholics. Univariate Analysis (Odd Ratio) of the data showed that presence of at least one parent does not have a significant impact on workaholism, but death of both parents may be a cause of workaholism. In early life, a child's parents are often the primary source for developing a sense of self-worth and learning effective ways of exercising personal control (Brown \& Harris, 1978; Leondari \& Kiosseoglou, 2002). According to Richman and Flaherty (1986), the effects of early parental care on children persist into adulthood. This is important because research 
suggests that high levels of self-esteem and personal control beliefs are positively associated with favorable mental and physical health outcomes, including psychological wellbeing, self-reported health status, avoidance of health risk behaviors, and recovery from illness (Duncan \& McAuley, 1993; Jenkins, Stanton \& Jono, 1994; Rodin, Timko \& Harris, 1985).

The socio-psychological and family literature suggests that marriage is a legal bond between husband and a wife, which provides normal family environment to the family members and is a special asset to the developing children. That gives the feeling of belonging, hence any disruption, physical or psychological, deprives a child of this very important feeling. Families lacking marital cohesion may develop personality problems among children that could be a reason why greater number of workaholics reported parental marital disharmony. The parental marital disharmony was found to be independently associated with workaholism. Thus, it can be concluded that workaholism is a consequence of low social support and feeling of neglect,etc . According to Hughes, (2005), low social support is linked to high risk of adverse health complaints. The multivariate analysis of the present data showed that parental marital disharmony is one of the leading factor reported by workaholics. The results also showed problem with sleep and hypertension as a major complaint by most of the workaholics, which may represent an increased lifetime risk of cardiovascular disease and other health-related problems.

The uniqueness of this study is the in-depth investigation of family problems. Severe illness of the parents is an important source of stress which may have serious consequences. Similarly other factors such as death of one parent, parental separation, polygamy were investigated but the results did not support these factors as causes of workaholism.

The findings of this study are in line with previous ones that health-related problems happen from extended working hours (Spurgeon, Harrington, Cooper, 1997). People who work a great deal of overtime are more likely to report high level of stress, strain, ill-health and higher chances of hypertension (Sparks, Cooper, Fried Shirom, 1997, Wada, 2006), acute myocardial infarction (Sokejima S, Kagamimori S, 1998 \& Liu Y, Tanaka H, 2002) and sleep problems (Schwartz et al., 1999 and Tachibana et al., 1996) which in turn results in serious diseases. Consistent with these findings, workaholics report long working hours and health complaints i.e. hypertension and headache or stomachache (McMillan et al., 2001; Spence and Robbins, 1992) and sleeplessness 
problem. The research findings suggest that increase in extra number of working hours leads to decrease in normal sleep hours with a significant increase in fatigue and reduced levels of alertness (Carey \& Fishburne, 1989). Working more than 48 hours a week leads to increased competition between sleep and other work-related activities of daily life that in turn results in a significant reduction in sleep (Dawson, 1997). Duration as well as quality of sleep may also suffer (Fischer et al., 1993, 2000; Peternitis, 1980). The findings of the present study suggest that sleeplessness problem is independently associated with workaholism and it is one of the most important characteristic of workaholics, which may further create physical and mental health problems for them.

According to the study findings workaholics are highly educated people and earn a handsome amount of money that improves the quality and standard of their life. It means that workaholism is not altogether a bad phenomenon but since compulsively long working hours are linked with stress and health-related risk that can even cause a sudden death (Uehata, 1991) that's why healthy and optimal level of working behavior is required for a healthy life.

The findings of the this study are in line with the existing literature on dysfunctional family as a cause of workaholism and healthrelated problems as a consequence but it is important to note that the present research explored cases which did not report any dysfunctional family environment during their early years of life. It was also found that there were cases of people who did not have any health-related problem. It is, therefore, suggested that it is not necessary that dysfunctional family is the only cause of workaholism. There could be other variables that may lead to workaholism. A possibility for variation in consequences is there as well.

Limitations of the present study must be kept in mind while interpreting the results: sampling strategy and use of new measure to assess workaholism: cross sectional research using convenient sampling technique, data were collected at one point in time making it difficult to address issues of causality. The sample was restricted on purpose to educated, fulltime employees of different profession working in Peshawar (Khyber Pakhtunkhwa, Pakistan). However efforts were made to ensure an unbiased selection of the sample. It was a self-report study, raising the issue of common method variance (response biases or attribution processes).

Finally the severity of hypertension and sleep disturbance was 
assessed by a single item that cannot differentiate between different kinds of hypertension and sleep disorders. A more detailed assessment might be helpful in diagnostic terms for example isolated systolic hypertension and isolated diastolic hypertension. Similarly for sleep disorders, a thorough appraisal is needed such as which kind(s) of sleep disorders are more prevalent in workaholics such as narcolepsy, sleep apnea and insomnia, etc. This should be taken up in more detail in future studies.

The findings of the present research provide support for the need to conduct more research on workaholics in other areas of Islamic Republic of Pakistan that should include all the important age groups. The literate and illiterate both should be given importance, house wives, temporary workers and unemployed people from both urban and rural areas should be approached. Longitudinal studies will also help better understand the construct of workaholism

\section{Conclusion}

Workaholism is on the rise and the society has a demand for it. The findings of the present study and the previous ones conducted on the subject show that the people living in technologically developed countries and Third World states like Pakistan have the vulnerability to workaholism.

The present study revealed six very important causal factors of workaholism out of twenty factors studied. They are age of workaholics, parental marital disharmony, economic crisis faced, higher education and health-related problems such as problem sleeping and hypertension. Those children or adolescents who face economic crisis or are raised in the family where there is a lack of marital harmony between parents are highly prone to workaholism. As a result when as an adult workaholic they will mostly exhibit workaholic behavior at the age of 28-35 years with higher education and quality of life lacking health i.e. suffering from hypertension and sleep problems, which means that they are highly vulnerable to cardiovascular diseases and even early death. It is important to note that it is not necessary that only workaholics can go an extra mile, and its only workaholics who are hard workers non-workaholics can also be hard workers.

\section{Acknowledgement}

The authors express gratitude to Neil Fiore $(\mathrm{PhD})$ who granted permission for the use of the test of workaholism. The authors are also 
thankful to the participants who took part in this research.

\section{References}

Antonucci, T. C. \& Akiyama, H. (1987). Social networks in adult life and a preliminary examination of the convoy model. Journal of Gerontology, 42(5), 519-527.

Bartolome, F. (1983). The work alibi, when it's hard to go home. Harvard Business Review, 61, 66-74.

Berkman, K. F., Vaccarina, V., \& Seeman, T. (1993). Gender differences in cardiovascular morbidity and mortality: The contribution of social networks and support. Annals of Behavioral Medicine, 15, 112-118.

Brett, J.M., \& Stroh, L. K. (2003). Working 61 plus hours a week: Why do managers do it? Journal of Applied Psychology, 88, 67-78.

Brooks-Gunn, J., Duncan, G., Aber, J. (1997). Do neighborhoods influence child and adolescent development? American Journal of Sociology, 99, 2, 353-95.

Brown, G.W., \% Harris, T. (1978). The social origins of depression. New York: free Press. In Gottlieb, B. H. (1988). Marshaling social support: Formats, Processes and Effects. London: Stage: Pp 15-17.

Burke, R. J. (1999). It's not how hard you work but how you work hard: Evaluating workaholism components. International Journal of Stress Management, 6(4): 225-239.

Burke, R. J. (1999a). Workaholism in organizations: Gender differences. Sex Roles, 41(5/6), 333-345.

Burke, R. J. (1999b). Workaholism in organizations: Measurement validation and replication. International Journal of Stress Management, 6(1), 45-55.

Burke, R. J. (2000). Workaholism in organizations: Concepts, results and future research directions. International Journal of Management Reviews, 2, 1-19.

Burke, R. J. (2000b). Workaholism and divorce. Psychological Reports, $86,219-220$.

Burke, R. J. (2000c). Workaholism and extra-work satisfaction. The International Journal of Organizational Analysis, 7(4), 352-364.

Burke, R. J. (2001). Workaholism components, job satisfaction, and career progress. Journal of Applied Social Psychology, 31(11), 2339-2356. 
Burke, R. J., Matthiesen, S. B., \& Pallesen, S. (2006). Workaholism in organizations: Personality and work environment correlates. Personality and Individual Differences, 40, 1223-1233.

Burke, R. J., Richardsen, A. M., \& Martinussen, M. (2002). Psychometric properties of Psychometric properties of Spence and Robbins. measures of workaholism components. Psychological Reports, 91, 1098-1104.

Burke, R.J. (2000b). Workaholism in organizations: psychological and physical well-being consequences. Stress Medicine, 16, 11_/16.

Carey JC, Fishburne JI. (1989) A method to limit working hours and reduce sleep deprivation in an obstetrics and gynecology residency program. Obstet Gynecol. 1989;74:668-672.

Duncan, T. E., \& McAuley, E. (1993). Social support and efficacy cognitions in exercise adherence: A latent growth curve analysis. Journal of Behavioral Medicine, 16, 199-218.

Fassel, D. (1990). Working ourselves to death: The high cost of workaholism and the rewards of recovery. New York: HarperCollins.

Fiore, N. (1980). The Now Habbit to Marilyn Machlowitz, Workaholics: Living with them, working with them. New York: Addison-Wesley.

Fischer, F.M., Moreno, C.R. de c., Fernandez, R de L., Berworth, A., dos Santos, A.M. \& Bruni, A deC. (1993) 'Day-and shift workers' leisure time', Ergonomics, Vol. 36 (1-3), 43-49.

Fischer, F.M., Moreno, C.R.C., Borges, F.N.S. \& Louzada, F.M. (2000) 'Alertness and sleep after 12-hour shifts: differences between day and night work'. In S. Hornberger, P. Knauth, G. Costa \& S. Folkard (Eds) Arbeitswissenschaft in der betrieblichen Praxis 17: Shiftwork in the 21st Century, 43-48,Peter Lang: Frankfurt.

Flowers, C., \& Robinson, B. E. (2001). A structural and discriminant analysis of the Work Addiction Risk Test. Educational and Psychological Measurement, in press.

Fujimoto, T. (2014). Workaholism and mental and physical health. Japan labor review. Tokyo, ISSN 1348-9364, ZDB-ID 2134650-1. - Vol. 11.2014, 1, p. 50-67.

Golińska, L. (2006): Pracoholizm małżonka irodzica w percepcji iodczuciach współpartnera I dzieci. Nowiny Psychologiczne, 1, 4755.

Golińska, L. (2008): Pracoholizm. Uzależnienieczypasja, Difin, Warszawa, $184 \mathrm{p}$.

PESHAWAR JOURNAL OF PSYCHOLOGY AND BEHAVIORAL SCIENCES, 2017, VOL. 3, NO. 1, 105-121 
Hughes, B.M. (2005). Work social support and workaholism among university staff: Imact on physical and mental well-being. Twenty-sixth Annual Conference of the Stress and Anxiety Research Society, Halle, Germany, July.

Jenkins CD, Stanton B, Jono RT. (1994). Quantifying and predicting recovery after heart surgery. Psychosom Med.1994; 56: 203-212.

Klaft, R. P., \& Kleiner, B. H. (1988). Understanding workaholics. Business, 38(3), 37-40.

Kubota, Kazumi, Akihito Shimazu, Norito Kawakami, Masaya Takahashi, Akinori Nakata, and Wilmar B. Schaufeli. 2011. Association between workaholism and sleeping problems among hospital nurses. Industrial Health 48, no. 6: 864-71.

Leondari, A., \& Kiosseoglou, G. (2002). Parental, psychological control and attachment in late adolescents and young adults. Psychological Reports, 90, 1015-1030.

Liu Y., \& Tanaka H. (2002). Overtime work, insufficient sleep and risk of non-fatal acute myocardial infarction in Japanese men. Occupational Environmental Medicine, 59(7), 447-451

Machlowitz, M. (1980). Workaholics. New York: Mentor.

Mayer, S.E. (1997). What money can't buy: The effects of parental income on children's outcomes. Cambridge, MA: Harvard University Press, 1997.

McMillan, L. H. W., \& O’Driscoll, M. P. (2008). The wellsprings of workaholism: A comparative analysis of the explanatory theories. In R. J. Burke \& C. L. Cooper (Eds.), The long work hours culture: Causes, consequences and choices (pp. 85-111). Bingley: Emerald.

McMillan, L. H. W., O.Driscoll, M. P., Marsh, N. V., \& Brady, E. C. (2001). Understanding workaholism: Data synthesis, theoretical critique, and future design strategies. International Journal of Stress Management, 8, 69-91.

Minirth, F., Meier, P., Hemfelt, R., Sneed, S., \& Hawkins, D. (1991). Love hunger. Fawcett Columbine, NY: Ballantine Books.

Naughton, T. J. (1987). A conceptual view of workaholism and implications for career counselling and research. Career Development Quarterly, 5, 137-148.

Oates, W. (1971). Confessions of a workaholic. New York: World Books.

Oates, W.E. (1968). On being a workaholic: A serious jest. Pastoral Psychology, 19, 16-20.

Overman, S. (1999). Rise and sigh. HR Magazine, 44(5), 68-74. 
Owuamanam, D. O. (1984). Adolescents' perception of the polygamous family and its relationship to self-concept. International Journal of Psychology, 19(6), 593-598.

Peternitis, C. (1980) 'Shiftwork: Work load, Fatigue and States of Vigilance'. In A. Reinberg, N. Vieux \& P. Andlauer (Eds) Night and Shiftwork Biological And Social Aspects: Advances in the Biosciences, Volume 30, 171-177, Pergamon Press: Paris.

Richman J, and Flaherty, JA. (1986). Childhood relationships, adult coping resources and depression. Social Science Med 23(7):709716.

Robinson, B. E. (1989). Work addiction. Deerfield Beach, FL: Health Communications.

Robinson, B. E. (1996). The psychosocial and familial dimensions of work addiction: Preliminary perspectives and hypotheses. Journal of Counseling \& Development, 74, 447-452.

Robinson, J. P. (1990). The leisure pie (use of leisure time). American Demographics, 12, 39.

Rodin, J., Timko, C., \& Harris, S. (1985). The construct of control: Biological and psychological correlates. Annual Review of Gerontology and Geriatrics (vol 5) (pp. - 55). New York: Springer.

Schwartz, S. H. (1999). A theory of cultural values and some implications for work. Applied Psychology: A International Review, 48, 23-47.

Shellenbarger, S. (1999) Work and family essays from the Wall Street Journal, Ballantyne Books, New York.

Shimazu, Akihito, and Hisashi Eguchi. (2012). Work engagement: A literature review on current situation and future directions. Occupational Health Review 25, no. 2:79-97.

Smit, P.J. \& Cronje, G.J. (2001). Management Principles. A Contemporary Edition

Sokejima S, Kagamimori S (1998) Working hours as a risk factor for acute myocardial infarction in Japan: case-control study. BMJ 317, 775-80.

Sparks, K., Cooper, C., Fried, Y., \&Shirom, A. (1997). The effects of hours of work on health: A meta-analytic review. Journal of Occupational and Organizational Psychology, 70, 391-408.

Spence, J. T. \& Robbins, A. S. (1992). Workaholism: Definition, measurement, and preliminary results. Journal of Personality Assessment, 38, 160-178.

PESHAWAR JOURNAL OF PSYCHOLOGY AND BEHAVIORAL SCIENCES, 2017, VOL. 3, NO. 1, 105-121 
Spurgeon A, Harrington JM, Cooper CL (1997) Health and safety problems associated with long working hours: a review of the current position. Occup Environ Med 54, 367-75.

Tachibana, N., Shinde, A., Lkeda A, Akiguchi I, Kimura J, Shibasaki H, (1996). Supplemetary motor area seizure resembling sleep disorder. Sleep 1996; 19 (10):811-6

Thorne, P. (1987). Workaholism: The acceptable face of addiction? International Management, 42(6), 71.

Uehata, T. (1991). Karoshi due to occupational stress related cardiovascular injuries among middle-aged in Japan. Journal of Science Labor, 1991;67:20-8.

Uehata, T. (1991). Long working hours and occupational stress-related cardiovascular attacks among middle-aged workers in Japan. Hum Ergol (Tokyo) 1991; 20: 147-153.

Wada, K., et al. (2006). Effects of overtime on blood pressure and body mass index in Japanese male workers. Occupational Medicine, 2006, 56(8): 578-580.

Wojdyło, K (2010): Pracoholizm. Perspektywapoznawcza, Difin, Warszawa, $134 \mathrm{p}$.

World Health Organization. (1946). Preamble to the Constitution of the World Health Organization as adopted by the International Health Conference. Official Records of the World Health Organization, 2, 100 . 